\title{
Harnessing India's Demographic Dividend through Skilling: Challenges and Way Forward
}

\section{Zahra Afroz}

Research Associate, National Skill Development Agency (NSDA), Ministry of Skill Development \& Entrepreneurship, Government of India, New Delhi, India

Corresponding author: zahaf9@gmail.com

\begin{abstract}
The 'demographic dividend' provides India with strong advantages for achieving high rates of growth powered by an enlarging working age population. This represents a huge opportunity for the country to increase productivity by investing in the skills of the working age population. A vast majority of who have limited access to education and training; are either inactive or engaged in low-skilled work in the informal economy. India's demography therefore, presents a potential danger also; if the labour market is not made more inclusive through a balanced approach to human capital development, the consequences of demographic failure could be grave. To capitalize on the demographic bulge, the Government has undertaken a number of policy initiatives, programmatic and systemic interventions. Efforts are being made to equip youth with the skills required by today's industries and address the demand \& supply gaps, but this is turning out to be a daunting task. In this context, the present article analyses the current state of education, skills development and employment for Indian youth and discusses some major challenges India faces while implementing different initiatives and strategies for developing a robust skilling ecosystem. The article also highlights certain emerging issues which merit immediate policy attention if skill development is to be a means for achieving inclusive development.
\end{abstract}

Keywords: Demographic dividend, Labour Force, Employment growth, Skill development, VET, Vocational training

India is the second most populous country in the world, with 17.5 per cent of the world's population, second only to China. More than half (60.3 per cent) of India's population falls within the working age category of 15-59 years and about a quarter (27.5 per cent) in the youth category of $15-29$ years (Census of India, 2011). The figures today reflect that India has the world's largest youth population comprising around one -fifth of the total world youth population. It is estimated that by the year 2020, the average age in India would be 29 years compared to 37 years in China and US and 45 years in Europe and 48 years in Japan (Chandrasekhar et al. 2006). India's demographic bulge can translate into a demographic dividend lest this human resource takes shape of a productive quality workforce through interventions in the areas of healthcare, education, skill training and creation of sustainable employment opportunities, failing which the supposed demographic advantage could turn into a demographic disaster.

Bloom and Canning (2004) using cross country panel data from 1965-1995, have shown a positive and significant relationship between the growth rate of the share of the working age population and economic growth, but only if the economy is open. The authors argued that the link between population growth and economic growth has to be established through sound institutions, flexible labour laws and good governance. They have presented the cases of Ireland and Taiwan, which have successfully reaped the benefits of the demographic dividend. They have shown that Ireland benefited from lower fertility in the form of higher labour supply per 
capita and Taiwan benefited through increased savings rates. The authors have shown that Latin American countries too had a similar opportunity for recouping investment but they wasted it due to the lack of relevant policies. Therefore, there are examples of both demographic dividend as well as demographic debacles. The authors emphasized that the realization of the potential benefits associated with the demographic transition appears to be dependent on institutions and policies, requiring the productive employment of the potential workers and savings the transition generates. Bloom, Canning and Malaney (2000) and Mason (2001) conclude that East Asia's 'economic miracle' was associated with a major transition in age structure, while Bloom, Canning and Sevilla (2002) find that much of Africa's relatively poor economic performance can be accounted for by the lack of such a transition. Dhillon and Yousef (2007) argued that it is a nation's success or failure in realizing the economic potential of young people during this 'low dependency ratio' period that can make the difference between sustained and faltering longterm development.

India has made remarkable progress in economic growth, poverty reduction, and human development during last decade. Between 2001 and 2011, the GDP grew at an average of 7.5 per cent per year and at an average of 6.7 per cent since 2012 (2012 to 2016). The Government of India, has now an ambitious plan to transform the country into a modern, competitive, high growth, high productivity developed economy. However, India's growth and global competitiveness are constrained by the low skill levels of its population. At the same time, large sections of the country's youth are looking for economic and livelihood opportunities. Government of India has accorded high priority to skill development in order to take advantage of the demographic bulge of the country and to fulfil the aspirations of youth for gainful employment and to contribute to national productivity. The high priority given to skill development is fully justified by evidence that training, defined as the provision of knowledge and job-related skills that complement those provided through general education, can be a powerful instrument to increase the human capital of individuals, facilitate their integration into the labour market, improve their earnings and livelihood opportunities, and foster growth.
In this paper we look into the enormity of challenges being faced by the Government to enhance the skill level of the youth population for capitalizing the demographic dividend and fostering inclusive development. The study is based on secondary data collected from various sources particularly government publications. The following section illustrates a picture of India's present and future demographics. The next section discusses the employment scenario in India and analyses the current education and training opportunities, followed by an assessment of skill needs and gaps in the country and also considers the constraints Government is facing in skilling the young population. The last section provides the conclusion.

\section{The Indian Demographics}

The demographic dividend - according to United Nation Population Fund (UNFPA) means- 'the economic growth potential that can result from shifts in a population's age structure, mainly when share of the working-age population (15 to 64) is larger than the non-working-age (14 \& younger and $65 \&$ older) share of the population'. Before the dividend begins, the country is burdened with a high dependency ratio with a large and growing share of the population below the working age population of 15 . Once the dividend period has passed, the share of the elderly population rises, which are no more working and hence to be provided with pension, health benefits, etc.

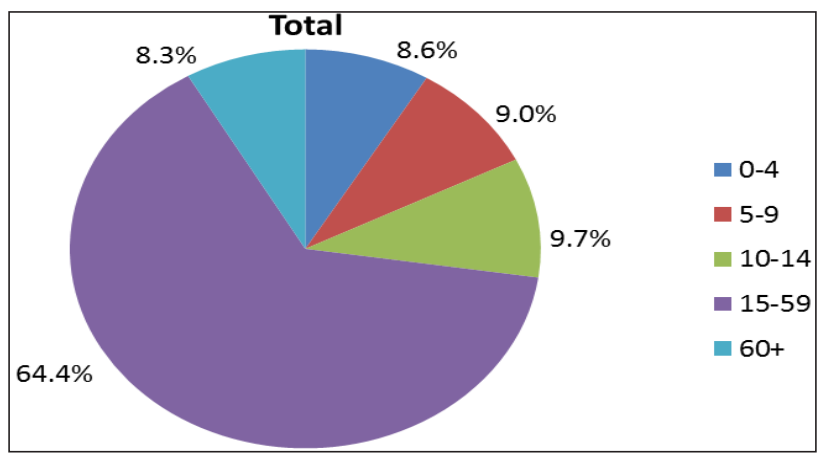

Fig. 1: Percentage distribution of population by broad age groups, 2015

Source: http://www.censusindia.gov.in/vital_statistics/SRS Report_2015/6.Chap\%202 Population\%20Composition-2015.pdf accessed on 15.7.2017

India's demographics show that India is home to relatively the youngest population across the world. It can be seen from the Fig. 1 and Table 1 (Appendix) 
that in 2015, the total working age population in India was 64.5 per cent of the total population, which is projected to rise to 68.3 per cent by 2040, after which a declining trend in the share of the working age population would be seen.

The table also indicates that the rising trend in the working age population, in fact, started during 1970 which as per government data is accompanied by a sharp fall in the crude birth rate and the total fertility rate. From Table 2 (Appendix), it is seen that the rising trend in working age population is also accompanied by a falling trend in the total age dependency ratio and child dependency ratio. This implies that the bulge in the working age population can be attributed to a decline in the number of dependent individuals in the age group of $0-14$ years (as reflected in the falling crude birth rate and the total fertility rate).

The Government data shows that there has been a gradual decline in the share of population in the age group 0-14 from 41.2 to 38.1 per cent during 1971 to 1981 and 36.3 to 27.3 per cent during 1991 to 2015, whereas, the proportion of economically active population (15-59 years) has increased from 53.4 to 56.3 per cent during 1971 to 1981 and 57.7 to 64.4 per cent during 1991 to 2015. And the percentage of elderly population (60+) exhibits a rising trend and has gone up from 5.3 to 5.7 per cent and 6.0 to 8.3 per cent respectively during the periods under reference (SRS, 2015). The old age dependency ratio has been forecast to rise continually, implying that the dependency would shift from the lower to the higher age groups due to the ageing of the population by 2050 .

\section{Labour market structure in India}

\section{Unusual Structural Transformation of the economy}

After Independence, in 1950 agriculture accounted for about 55 per cent of GDP, industry about 13 per cent and services about 27 per cent. In respect of the share of labour force in different sectors, agriculture accounted for about 75 per cent, industry for about 11 per cent and services 16 per cent of total employment in 1950. During the process of structural transition, the share of agriculture in GDP has declined to 36.38 per cent in 1983 to 23.18 per cent in 1999-2000 and further to 14.37 per cent in
2011-12 (GDP at factor cost, 2004-05 prices). That of industry increased to 24 per cent in 1983 and slowly to 26.77 per cent in $1999-2000$ and to 28.22 per cent in 2011-12. Share of services increased to 40 per cent in 1983 and to 50.05 per cent in 19992000 and further reached to 57.42 per cent during 2011-12 (CSO, MOSPI).

The acceleration in growth of GDP in different sectors is not accompanied by a commensurate growth in employment. Share of agriculture in employment declined to 68.52 per cent in 1983 to 60.27 per cent in 1999-2000 and further to 48.9 per cent in 2011-12. Share of Industry in employment increased to 13.83 per cent in 1983 to 16.22 per cent in 1999-2000 and further to 24.3 per cent in 2011-12. While share of services increased from 16 per cent in 1950 to 17.65 per cent in 1983 to 23.5 per cent in 1999-2000 and further to 26.8 per cent in 2011-12 (NSSO, MOSPI).

The above analysis shows that agriculture continues to be the dominant sector in terms of employment absorption, although one can see a gradual decline. It is still the largest employer accounting for 49 per cent of overall employment (NSS, $68^{\text {th }}$ round). A closer look reveals that in the secondary sector; in manufacturing, both income and employment seems to be almost stagnant. The manufacturing employment has remained at a low level of 11-12 per cent for the last three decades and its share in Gross Domestic Product has stagnated at 15-16 per cent during the same period. The main driving force behind the growth is 'the service sector' which constitutes a major share (57.42 per cent) of GDP but contributes a significantly lower share (26.8 per cent) in employment.

Table 1: Trends in sectoral output and employment (UPSS basis)

\begin{tabular}{|c|c|c|c|c|}
\hline \multirow[t]{2}{*}{ Sectors/Subsectors } & \multicolumn{2}{|c|}{$\begin{array}{c}\text { Sectoral } \\
\text { GDP share } \\
(\%) \\
\end{array}$} & \multicolumn{2}{|c|}{$\begin{array}{c}\text { Sectoral } \\
\text { Employment } \\
\text { Share (\%) }\end{array}$} \\
\hline & $\begin{array}{c}2004- \\
05\end{array}$ & $\begin{array}{c}2011- \\
12 \\
\end{array}$ & 2004-05 & $\begin{array}{c}2011- \\
12 \\
\end{array}$ \\
\hline Primary Sector & 19 & 14.4 & 58.3 & 48.9 \\
\hline $\begin{array}{c}\text { Agriculture, Forestry \& } \\
\text { Fishing }\end{array}$ & 19 & 14.4 & 58.3 & 48.8 \\
\hline Secondary Sector & 27.93 & 28.22 & 18.1 & 24.3 \\
\hline Mining \& Quarrying & 2.9 & 2.1 & 0.6 & 0.5 \\
\hline Manufacturing & 15.3 & 16.3 & 11.6 & 12.5 \\
\hline
\end{tabular}




\begin{tabular}{|c|c|c|c|c|}
\hline $\begin{array}{l}\text { Electricity, Gas \& Water } \\
\text { Supply }\end{array}$ & 2.1 & 1.9 & 0.3 & 0.5 \\
\hline Construction & 7.7 & 7.9 & 5.6 & 10.6 \\
\hline Service Sector & 53.1 & 59.0 & 23.4 & 26.8 \\
\hline $\begin{array}{l}\text { Trade, Hotels and } \\
\text { restaurant }\end{array}$ & 16.1 & 16.1 & 10.3 & 11.0 \\
\hline $\begin{array}{l}\text { Transport, storage \& } \\
\text { Communication }\end{array}$ & 8.4 & 10.6 & 3.9 & 4.9 \\
\hline $\begin{array}{l}\text { Financing, Insurance, Real } \\
\text { Estate \& Business Services }\end{array}$ & 14.7 & 18 & 1.6 & 1.1 \\
\hline $\begin{array}{c}\text { Community, Social \& } \\
\text { Personal Services }\end{array}$ & 13.8 & 12.7 & 7.8 & 10.0 \\
\hline
\end{tabular}

Note: (a) Income refers to GDP at factor cost at 2004-05 prices; (b) employment refers to UPSS (usual principal and subsidiary status), data is from $61^{\text {st }}$ and $68^{\text {th }}$ Rounds of NSSO's EmploymentUnemployment Survey (c) Sector wise classification remains same as CSO for comparison; Source: Based on CSO and NSSO various years.

Disconnect between GDP and employment growth and a shift straight from agriculture to services led growth, leapfrogging manufacturing, have been a distinct feature of India's structural transformation. This is unlike the most developed countries and more recently the East Asian Countries which entered the phase of predominance of services in their economies after going through a phase of industrialisation. Such sectoral composition of growth and employment points towards India's inability to create a balanced mix of 'employment' and 'quality employment', where quality signifies productivity contribution. The Economic Survey, 2014-15 observes that a major impediment to the pace of quality employment generation in India is the small share of manufacturing in total employment. The major challenge India has been facing is to raise the share of manufacturing in both income an employment.

Structural transformation of the economy leads to large scale migration of workforce from primary to secondary and tertiary sectors. In India, the bulk of labour force moving out of agriculture has been absorbed in construction (non-manufacturing), and low end service sector within the informal economy viz., hotel, restaurant, whole and retail and personnel services. In other words, structural changes of Indian economy have led to a shift of labour from informal sector of agriculture to informal sector of the non agriculture largely due to lack of any form of education and vocational training. There is a large share of self-employed workers within non-agricultural sector, whose productivity tends to be generally low in most occupations.

Skill development is thus envisioned by the Government as a way to foster structural changes, facilitate shifts from low-skilled towards higherskilled occupations and from manual/primitive production structure to more technology intensive, innovative and knowledge-based production in the context of globalization. This will increase efficiency in the production process and create better labour outcomes. Skill development is thus envisaged to be an integral part of employment and economic growth strategies of the country.

\section{Employment status}

India's labour market is highly stratified and segmented. As per Government data, only $6.9 \%$ of the total workforce is in the organized sector, defined as private-sector firms employing 10 or more workers and all public sector enterprises. Within the organized sector, the private sector is fairly small, accounting for only $2.2 \%$ of total employment. The remaining $93 \%$ of employees work in the unorganized sector, defined as private enterprises with under 10 employees, the selfemployed, and casual and family workers.

Table 2: Distribution of workers by nature of employment (per cent)

\begin{tabular}{ccccc}
\hline Approach & $\begin{array}{c}\text { Self } \\
\text { employed }\end{array}$ & $\begin{array}{c}\text { Wage/ } \\
\text { salary } \\
\text { earners }\end{array}$ & $\begin{array}{c}\text { Contract } \\
\text { worker }\end{array}$ & $\begin{array}{c}\text { Casual } \\
\text { labour }\end{array}$ \\
\hline UPS & 49.5 & 16.5 & 3.0 & 30.9 \\
UPSS & 50.5 & 15.4 & 2.9 & 31.1 \\
\hline
\end{tabular}

Source: Report on Fourth Annual Employment - Unemployment Survey (2013-14), Volume I, Labour Bureau, Ministry of Labour $\mathcal{E}$ Employment, GOI.

The nature of employment provides important insights into the quality of work. The above table shows that based on UPS approach, about 50 per cent of the work force was self-employed followed by 31 per cent as casual labour, the proportion of work force with regular wage or salary was just 17 per cent, and remaining 3 per cent as contract workers. Under the UPSS approach also same pattern was visible. Most of the self-employed was engaged in agriculture, while casual labour was mostly engaged 
in the agriculture and construction sector. A closer look reveals that, on the whole around 50 per cent of the workforce was self employed, of which own account workers were around 33 per cent and the unpaid helper 18 per cent. We observe that, skill development of the self employed is essential to make the transition from own account workers to employers or entrepreneurs.

Table 3: Unemployment rate by age cohort and sex (per cent) (CDS basis)

\begin{tabular}{ccc}
\hline Age/Survey Years & $\mathbf{2 0 0 4 - 0 5}$ & $\mathbf{2 0 1 1 - 1 2}$ \\
\hline $15-24$ & 14.8 & 13.3 \\
25-34 & 8.5 & 5.9 \\
35 and older & 5.3 & 3.1 \\
Total & $\mathbf{8 . 3}$ & $\mathbf{5 . 6}$ \\
\hline
\end{tabular}

Source: Employment and Unemployment Survey (NSSO), 61 $1^{\text {st }}$ and $68^{\text {th }}$ round, calculated from unit level data.

The unemployment rate indicates the proportion of people in the labour force seeking work but unable to find. One of the major concerns regarding the Indian labour market is the relatively high youth unemployment rate. While the open unemployment rate (for all age groups) has been relatively low, the rate of unemployment among youth has been almost double the overall rate. The following section will through light on the educational and sectoral employment status.

\section{Educational status of India's labour force}

Overall educational attainment of the population is a common indicator for assessing the skill base. Indeed, employment opportunities are closely linked with the level of educational attainment, as evidenced in a sample survey (Desai et al. 2010). The educated are much more likely to work as regular wage or salaried workers, earning high wage premiums. The composition of the India's labour force by educational attainment shows that the majority of the workforce is still 'minimally educated,' i.e., with no schooling at all or only primary level (Fig 2).

In 2011-12, 30 per cent of the labour force was illiterate, while 24 per cent was able to attain only below primary or primary level of education, which implies that 54 per cent of the Indian labour force had negligible or extremely low levels of education in 2011-12. The figures for those having acquired middle, secondary level was 16.4 per cent, 12 per cent respectively. The remaining only 17.6 per cent had attained higher secondary and higher levels of education (including diploma/ certificate, graduation, and post graduation levels of education).

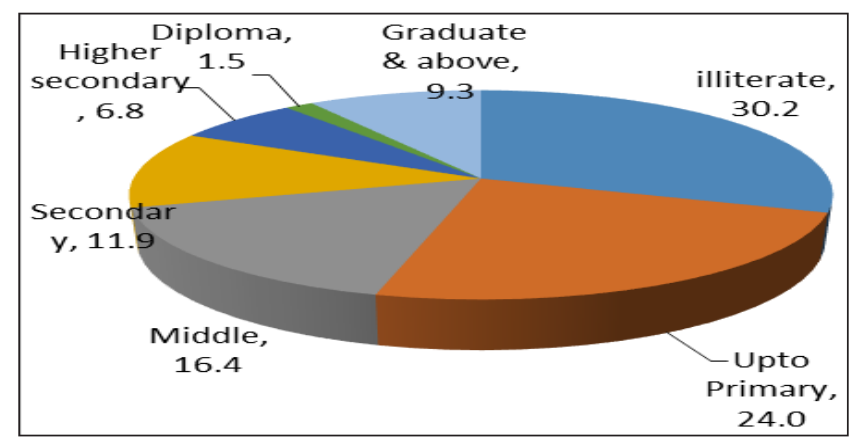

Fig. 2: Education Profile of Labour Force in India in 2011-12 (per cent)

Source: Employment and Unemployment Survey (NSSO), $68^{\text {th }}$ round calculated from unit level data

A look at the profile of work force by economic sectors as given in Table 4 , indicates that the proportion of illiterate workers is highest in agriculture and allied activities (about 40 per cent), followed by the non-manufacturing sector (33 per cent), manufacturing (20 per cent) and remaining 12 per cent of the services work force were illiterate.

Table 5 indicates the abysmally low share (only around 17.92 per cent of persons in the age group 15-59 years) of those who have received or were enrolled in some type of vocational training in the country. While the proportion of workforce with formal training was (received as well as undergoing training) was 3.05 per cent during 2011-12, the proportion of workforce that received training through informal modes was also very low at only 14.87 per cent. The skills base of an economy is a determinant of opportunities for decent employment. With about 75.8 per cent of the work force not having received any form of skill training during 2011-12, speaks volume about the inability of these people to get formal/organised sector jobs. No wonder, they are compelled to take up low paid, unproductive jobs in the informal sector. A closer look, reveals that only 2.7 per cent of persons aged 15-59 years and 3.4 per cent of those aged 15-29 years had received or were enrolled in some form of technical education in 2011-12.So the country faces the challenge of large cohorts of new labour 
Table 4: Estimated number of workers (PS+SS in age group 15-59) by level of education by sector (millions), 2009-10

\begin{tabular}{cccccc}
\hline Level & $\begin{array}{c}\text { Agriculture and } \\
\text { Allied }\end{array}$ & Manufacture & Non-Manufacture & Service & Total \\
\hline Not Literate & 87.36 & 9.56 & 14.42 & 13.65 & 124.99 \\
Literate without formal schooling & 1.23 & 0.25 & 0.21 & 0.42 & 2.11 \\
Below primary + Primary & 57.62 & 12.69 & 12.47 & 18.32 & 101.10 \\
Middle & 36.20 & 10.27 & 8.67 & 18.98 & 74.12 \\
Secondary & 21.30 & 7.02 & 4.27 & 18.21 & 50.79 \\
Higher secondary & 10.36 & 3.21 & 1.45 & 12.43 & 27.45 \\
Diploma/certificate course & 0.58 & 1.16 & 0.53 & 3.12 & 5.39 \\
Graduate & 3.84 & 3.01 & 1.25 & 17.82 & 25.93 \\
Graduate and above & 0.74 & 0.73 & 0.24 & 7.00 & 8.70 \\
Total & $\mathbf{2 1 9 . 2 3}$ & $\mathbf{4 7 . 9 0}$ & $\mathbf{4 3 . 5 0}$ & $\mathbf{1 0 9 . 9 6}$ & $\mathbf{4 2 0 . 5 9}$ \\
\hline
\end{tabular}

Source: Twelfth Five Year Plan (2012-2017) volume 3, Social Sectors

Table 5: Distribution of vocationally trained work force (PS+SS in the age group 15-59) (per cent), 2011-12

\begin{tabular}{cccccc}
\hline Status of vocational training & Agriculture & Manufacturing & Non-Manufacturing & Services & Total \\
\hline Receiving formal training & 0.08 & 0.13 & 0.05 & 0.39 & 0.64 \\
Received formal training & 0.22 & 0.51 & 0.20 & 1.48 & 2.41 \\
Received non- formal training & 4.8 & 4.06 & 1.6 & 4.41 & 14.87 \\
Did not receive any training & 38.22 & 7.56 & 9.45 & 20.56 & 75.80 \\
NR & 5.81 & 0.85 & 0.55 & 1.48 & 8.69 \\
Total & $\mathbf{4 8 . 9 0}$ & $\mathbf{1 2 . 6 0}$ & $\mathbf{1 1 . 6 5}$ & $\mathbf{2 6 . 8 4}$ & $\mathbf{1 0 0}$ \\
\hline
\end{tabular}

Source: Sanghi and Srija, 2015, calculated from 68th round Employment and Unemployment Survey (NSSO) unit level data

force entrants who possess few or no job skills and cannot access decent jobs.

\section{Skill gap in India's labour market}

There exists a huge skill gap in the labour market, in terms of both quality and quantity. As per India Skills Report 2015, of all the students applying for roles in labour market, a mere $1 / 3^{\text {rd }}$ of the number had the appropriate skills to match the requirement of the employers. National Employability Report, 2014 by Aspiring Minds, shows that out of the six hundred thousand engineers that graduate annually, only 18.43 per cent are employable for the Software Engineer-IT services role, while a dismal 3.95 per cent are appropriately trained to be directly deployed on projects.

Several studies have highlighted the quantitative dimensions of skill gaps in different sectors in India. On demand side, a skill gap study conducted by National Skill Development Corporation (NSDC) over 2010-2014, estimated that there is an incremental human resource requirement of 109.73 million skilled manpower by 2022 in twenty four key sectors of the economy. Mehrotra et al. (2013) in their occasional paper 'Estimating Gap on a Realistic Basis for 2022' arrive at an incremental skilled manpower requirement of 291 million by 2022. The authors however, caution that what matters is not so much the number of those who would be skilled but the quality of skills that would be imparted.

The skill development issue is thus pertinent both at the demand and supply level. To meet the demand side challenge, consistent efforts are needed towards expansion of economic activities and creation of large employment opportunities. On the supply side, the issue is primarily related to employability of the labour force. Huge gaps exist between the industry requirements and the level of skills of workers due to varied reasons including inadequate training infrastructures, inappropriate mix of skills and education, outdated curricula, limited industry interfaces and limited standards, etc., (FICCI, 2015). 
Hence, both employment and employability are key factors of concern.

Realising the gravity of the situation, the Government of India took various initiatives to arrest the prevailing situation. In the $11^{\text {th }}$ Five Year Plan, a coordinated Action on Skill Development was initiated aiming at an appropriate policy formulation; synergizing efforts of different Ministries/departments, creating an institutional framework and expanding the education and training capacity etc., for creating an appropriate skilling ecosystem in the country. The Government of India has now adopted skill development as a national priority for over the next 10 years. To achieve the vision of 'Skilled India' on a mission mode, Ministry of Skill Development \& Entrepreneurship has been set up and an ambitious strategy outlined in the National Policy on Skill Development and Entrepreneurship, 2015 has been formulated. The Ministry is mandated for coordinating all skill development efforts across the country; aligning demand and supply of skilled manpower; building the vocational and technical training framework, skill up-gradation, building of new skills and innovative thinking for existing as well as new jobs to be created. The National Policy for Skill Development and Entrepreneurship, 2015 primarily aims at meeting the challenge of skilling at scale with speed, standards (quality) and sustainability. The Government has also initiated several systemic reforms for skilling the population and increasing their employability like operationalization of the National Skill Qualification Framework (NSQF), setting National Occupational Standards, establishment of Quality Assurance Framework, Recognition of Prior Learning(RPL), creation of a pool of trainers and assessors for quality and outcome based training etc.

\section{Challenges}

The West European and Japanese populations are already aging and their total populations have been declining. As per an analysis done by the US Department of Labour and Boston Consulting Group (2002-03), world is expected to witness a shortage of skilled manpower of approximately 56.5 million by 2020, while India could have a skilled manpower surplus of approximately 47 million (Planning Commission, 2008), if we could skill our youth population. India therefore, has the potential to meet not only its own domestic requirement fully but also be the supplier of skilled man-power to the rest of the ageing and aged world. However, significant challenges need to be addressed before we can reap the demographic dividend, as majority of young people have limited access to education and training and most find work in the informal sector. Although a large number of policy initiatives, programmatic and systemic interventions have been started; leveraging the demographic bulge through skilling is turning to be a daunting challenge. The Government of India through various convergence programme and systematic involvement of private sectors and other stake holders is trying to address the challenges in developing the skill ecosystem in the country. However, the following challenges are posed before the Government, which need specific and intensified interventions:

Unequal access: India's demographic bulge is not uniformly distributed across the country; while the Northern states would have young population, the Southern states have already started aging. According to Census population projections, the states of Assam, Bihar, Chhattisgarh, Jharkhand, Madhya Pradesh, Rajasthan and Uttar Pradesh would witness increase in the working age population in the next decade making them demographically young. However, these states have low Gross State Domestic Product (GSDP), inadequate infrastructure for education and skill development and also offer one of the lowest employment opportunities. Moreover, there is either no or inadequate training infrastructure in less developed districts/rural and far flung areas of the country, hence, great majority of youth from rural areas and economically and socially disadvantaged groups get very limited access to education and training. Women constitute almost half of the demographic dividend. They continue to be underrepresented in skill development programmes due to several reasons including transport, security and lack of women friendly environment etc,. They face constraints of choice, as emphasis for women training remained in low-return and traditional segments such as tailoring or beauty.

Absence of National Vocational Education and Training Standards: Over 18 Ministries/Departments of the Government of India are implementing over 
40 Skill Development Programmes (SDP) (MoSDE, 2016). Short term vocational training courses run under various programmes, at present are not able to meet the twin objectives of meeting the exact skills needs of the employers and provide decent opportunities of livelihood for youth at decent wages. It is also seen that National Occupational Standards (NOSs) and Qualification Packs (QPs) developed by the Sector Skill Councils (SSCs) are narrow, are mostly of small (generally of 150-300 hours) duration and do not meet the real industry needs, as a result of which the trained persons have not been employed by the sectoral industries.

Skilling formal school dropouts: As per U-DISE 2013-14, about 20 per cent children dropout before completing Class V and additional 16.5 per cent drop out before completing Class VIII. The total proportion of children who drop out before completing Class $X$ is about 47.4 per cent. When such early school leavers enter the labour market, they are absorbed as low paid unskilled workers in the informal economy. The challenge is to provide appropriate skill training to these set of labour force and also provide them a second chance to acquire basic numeracy, literacy and functional skills to move them out of low paid work in the informal economy.

Recognition of Prior Learning (RPL): Almost 93 per cent of the workforce is engaged in informal employment, which lacks any kind of structured skill development system of acquiring or upgrading skills. Here the skill formation takes place through hereditary transfer of knowledge, family occupations and on-the-job training under master craftsmen etc. However in absence of certification of their skills, they command low wages and are unable to move vertically or horizontally. In order to recognize and value these informal apprenticeships, a framework of RPL has been put in place. But one RPL model is not suitable for all qualifications and all situations; different approaches are required for RPL across various sectors to speed up RPL certification process.

Sustainability and retention: The challenge of dropouts- trainees who do not accept job offers or who leave jobs within a month of their start date, must be addressed comprehensively and immediately. Highly focused initiatives such as the Himayat program - a training and job-placement program for unemployed youth from low-income households in
Jammu and Kashmir - have experienced the same problem. Of the 1,245 youth who were trained and offered jobs in the first phase of the Himayat program, 950 took jobs. However, only 569 were found to be on their jobs after four to six months on the job, suggesting that around half of the batch dropped out (Pande, 2012).

\section{Shortage of Qualified Trainers and Assessors:} There is huge shortage of qualified trainers in the VET system an even more acute shortage of qualified and competent assessors to assess trainees. A significant proportion of trainers have neither the requisite teaching skills nor the relevant industry experience. Due to poor career growth prospects, attrition rate is also high among faculty in vocational institutes. The training capacity of the trainers currently stands at 8268 per annum against requirement of at least 20000 trainers per annum (MoSDE, 2016).

Inadequate monitoring and evaluation (M\&E): Monitoring arrangements are inadequate, with little third-party monitoring of quality and outcomes. Given the wide geographical spread of training centers and the range of training courses delivered by Training Partners under Skill development schemes (like PMKVY) across these centers, concurrent monitoring at the local level is inadequate. There is no formal and active feedback mechanism in place to capture 'learning experiences' of and 'outcomes' for the beneficiaries. Ensuring that funds received under various programmes are optimally utilised is also a big challenge.

\section{Suggestions}

Almost half of the current labour force is either illiterate or only has attended primary or upper primary education. Even though such workers may have acquired skills through informal means, they should get certification of their informally acquired skills, through Recognition of Prior Learning at the earliest. This would improve their employment prospects outside the informal channel. There is an urgent need to develop appropriate vocational education and training facilities to ensure equitable access for all and at the same time maintain their quality and relevance in the dynamic labour market. It is also required to create more courses at ITIs with lower levels of educational requirements for opening training opportunities for youths who 
have not completed the secondary education. Along with hard skills, soft skills, digital literacy, basic numeracy and financial literacy etc., should be made an integral part of each course curriculum. The technologies, manufacturing practices and service delivery systems are changing fast, so in order to keep pace with them, sound institutional mechanism need to be crated to visualize the future needs/changes and prepare people with those skills. There is need to initiate and scale up courses in the disciplines such as automation, nano-technology, artificial intelligence, robotics which can cater to the needs of Industry 4.0.

A strong need arises to lay down National Standards and Frameworks in Vocational Education \& Training (VET) like National Competency Standards, National Training Standards, National Accreditation Standards, National Assessment Standards, National Certification Standards etc., and align them to the respective International Standards. This will in turn scale up the employability of the labour force in both domestic as well as international labour markets. Almost all skill development programmes are implemented by respective departments at the state level and, inter alia, through their nodal agencies at the district level. Hence, unless convergence is concurrently taking place at the state level, its full benefits may not reach target groups. There is an urgent need to strengthen the State Skill Development Missions (SSDMs) as nodal bodies for convergence of all skilling initiatives in the state/ union territories, by fostering collaboration of the SSDMs with the NSDC and SSCs. It is also necessary to build planning, implementation and monitoring capacity of quality market-relevant training at national, state and district levels.

Vocational courses are terminal in nature, lacking vertical mobility from certificate to diploma to degree courses in vocational education. There is also a strong need for convergence among different line ministries particularly Ministries of Labour and Employment, Human Resource Development and of Skill Development and Entrepreneurship for charting out pathways for horizontal and vertical mobility of vocationally trained candidates and for those certified through RPL framework. This will in turn also help in reducing informalisation of employment in the country. Efforts should also be made to ensure that skills' training translates into sustainable livelihoods for youth, making it an aspirational career choice for them. Suitable policy interventions are required for integrating vocational education with school education. There are limited sources of relevant, frequently updated, and appropriately disaggregated data to signal industry demand to the young people and suppliers of trained personnel. Hence, the problem of information asymmetry needs effective resolution.

\section{CONCLUSION}

The Demographic Dividend is the economic benefit that arises from a significant increase in the ratio of working age adults, which can accelerate economic growth through the increased productivity of a relatively larger labour force, if there are adequate decent jobs for them. Presently, India is poised to realise the unique window of opportunity provided by the favourable age structure of its population. This is a however, a gigantic task given the poor level of skills and education possessed by the vast majority of those joining the workforce, and the overwhelmingly informal character of employment. To add to the woe, the access to education, training and employment opportunities is still largely determined by youths' socio-economic backgrounds, gender and geographic locations. Female and schedule tribe's participation in skill development programs is extremely low. Taking cognizance of the importance of skill development for our national development and global competiveness, Government has put in place the policy and institutional frameworks and dedicated resources for implementing the national skilling agenda. However, realization of this agenda requires active involvement and vigorous partnership among all the stake holders viz., government, suppliers of educational services, industry and civil society.

In order to make VET credible, serve the skill needs of the industry, provide employment opportunities to youth and be internationally comparable; it must be of very high quality. Hence, all the vocational training institutions must be accredited on the basis on National Accreditation Standards by independent professional bodies, create annual surveillance and oversight mechanism and ensure best quality training by way of assessment and certification. The Government has rightly shifted its focus recently from chasing the numbers to skill 
to providing quality training i.e., from outcome to output based training.

There is need to relook at model of short term training courses, as expenditure on them appears to be wastage of public resources without achieving the desired goals of providing employment to youth at decent wages and meeting the skill needs of the industry. Apprenticeship training provides for an industry led, practice oriented, effective and efficient mode of formal training. National Apprenticeship Promotional Scheme (NAPS) aims to promote apprenticeship training and increase the engagement of apprentice from present 2.3 lakh to 50 lakh cumulatively by 2020 . Effective implementation and monitoring of the NAPS will create an industry ready workforce and may transform the unorganized or informal sector through mutual benefits for the employer, the employee and the training organisations. As majority of beneficiaries are from rural areas with low socio-economic background, awareness generation and information dissemination regarding skill development schemes including NAPS remains a big issue. India's present model of financing VET also needs to be relooked, in line with the successful international models of VET financing being practiced in countries like UK, Brazil and Germany etc.

Skill development alone is not sufficient; there is need for availability of job opportunities for those skills. This requires robust labour legislation and supportive macro-economic policies related to infrastructure development, ease of doing business, entrepreneurial activities and creation of productive employment opportunities. Government needs to focus on the enforcement of the existing policies to ensure better utilisation of the existing resources and skill base, and promoting innovation in accordance with the demands of Indian labour market. National Manufacturing Policy, 2011 and 'Make in India' initiative aim at increasing manufacturing activity across various sectors and creating substantial number of jobs by 2022.

India's demographic dividend began in the early 1970s and is expected to come to an end towards latter part of 2030s. India is, therefore, just beyond the midpoint of its dividend and this once in a life time opportunity for the nation is expected to last for the next 25 years. India, therefore, needs to grow very fast and sustain its growth, reduce poverty and enhance the living standards of its people, which is possible only when youth are educated and equipped with skills which can transform the society in an ever changing technology-driven age.

\section{APPENDIX}

Table 1: Population aged 15-24 years, India

\begin{tabular}{ccc}
\hline Year & $\mathbf{( \% )}$ & Thousands \\
\hline 1960 & 56.3 & 252137 \\
1965 & 55.1 & 273478 \\
1970 & 55.7 & 308370 \\
1975 & 56.4 & 350612 \\
1980 & 56.9 & 398052 \\
1985 & 57.5 & 451188 \\
1990 & 58.3 & 509046 \\
1995 & 59.5 & 573715 \\
2000 & 61.1 & 543532 \\
2005 & 62.8 & 716391 \\
2010 & 64.5 & 789750 \\
2015 & 65.8 & 861118 \\
2020 & 66.6 & 923050 \\
2025 & 67.3 & 981726 \\
2030 & 67.9 & 1034326 \\
2035 & 68.2 & 1078019 \\
2040 & 68.3 & 1111744 \\
2045 & 68.1 & 1133073 \\
2050 & 67.6 & 1143065 \\
\hline & &
\end{tabular}

Table 2: Dependency ratios

\begin{tabular}{cccc}
\hline Year & Total & Child & Old Age \\
\hline 1960 & 78 & 72 & 5 \\
1965 & 82 & 76 & 6 \\
1970 & 80 & 74 & 6 \\
1975 & 77 & 71 & 6 \\
1980 & 76 & 70 & 6 \\
1985 & 74 & 67 & 6 \\
1990 & 72 & 65 & 6 \\
1995 & 68 & 61 & 7 \\
2000 & 64 & 57 & 7 \\
2005 & 59 & 52 & 7 \\
2010 & 55 & 47 & 8 \\
2015 & 52 & 44 & 8 \\
2020 & 50 & 41 & 9 \\
2025 & 49 & 38 & 11 \\
2030 & 47 & 35 & 12 \\
2035 & 47 & 33 & 14
\end{tabular}




$\begin{array}{llll}2040 & 46 & 31 & 15 \\ 2045 & 47 & 29 & 18 \\ 2050 & 48 & 28 & 20\end{array}$

Source: World Population Prospects: The 2010 Revision, Population Division of the Department of Economic and Social Affairs of the United Nations Secretariat, Available at: http://esa. un.org/unpd/wpp/index.htm.

\section{END NOTES}

Usual Principal Status (UPS or PS) measures those engaged in work for the largest part of the 365 days preceding the date of the survey.

Usual Principal and Subsidiary Status (UPSS or PS+SS) measures those employed under UPS and also includes those that are employed for at least 30 days during the 365 days prior to the date of survey; This is a more inclusive measure which covers, in addition, participation in economic activity on a more or less regular basis, of those classified as unemployed on the UPS as well as those as being outside the labour force on the same criterion.

Current Daily Status (CDS) measures the employment status in each day of the week preceding the date of survey.

National Occupational Standards (NOS): NOS define the measurable performance outcomes required from an individual engaged in a particular task. They list down what an individual performing that task should know and also do. Just as each job role may require the performance of a number of tasks, the combination of all the NOSs corresponding to these tasks would form the Qualification Pack (QP) for that job role.

Recognition of Prior Learning (RPL): RPL is the process of recognising previous learning, often experiential, towards gaining a qualification

Sector Skill Councils (SSCs): SSCs are industry-led and industry-governed bodies, which help link the requirements of industry with appropriately trained manpower.

\section{REFERENCES}

Bloom, D.E, Canning, D, and Sevilla, J. 2002. 'The Demographic Dividend: A New Perspective on the Economic Consequences of Population Change', Santa Monica, California: RAND, MR-1274.

Bloom, D.E. and Canning, D. 2004. 'Global Demographic Change: Dimensions and Economic Significance', Working Paper 10817, NBER Working Paper Series, Cambridge.
Chandrasekhar, C., Ghosh, J. and Roychowdhury, A. 2006. 'The 'Demographic Dividend' and Young India's Economic Future', Economic and Political Weekly, 41(49): 5055-64.

Chenoy Dilip 2015. 'Re-defining skills development landscape in India', Yojana, October 2015, New Delhi, 59: 7-9.

Dhillon Navtej and Tarik Yousef 2007. 'Inclusion: Meeting the 100 Million Youth Challenge', Middle East Youth InitiativeThe Wolfensohn Center for Development at Brookings \& the Dubai School of Government, Dubai.

Desai, S.B., Dubai, A., Joshi, B.L., Sen., M. Sharif, A. and Vann man, R. 2010. 'Human Development in India: Challenges for a Society in Transition'. New Delhi.

Government of India, National Sample Survey Office (NSSO) 2006. Employment and Unemployment Situation in India 2004-05, 61 ${ }^{\text {st }}$ Round, July 2004-June 2005, Report No. 515, Part I and II, NSSO, Ministry of Statistics and Programme Implementation, , New Delhi.

Government of India 2008. Eleventh Five Year Plan (20072012), Volume II, Social Sector. Planning Commission, New Delhi.

Government of India 2011. Report of the Working Group on Employment, Planning \& Policy for the Twelfth Five Year Plan (2012-2017), Labour, Employment \& Manpower (LEM) Division, Planning Commission, New Delhi.

Government of India 2011. Census of India- Population totals 2011, Office of the Registrar General and Census Commissioner, Ministry of Home Affairs, New Delhi.

Government of India, National Sample Survey Office (NSSO) 2011. Key Indicators of Employment and Unemployment in India (2009-10), 66 ${ }^{\text {th }}$ Round, July 2009- June 2010, NSSO, Ministry of Statistics and Programme Implementation, New Delhi.

Government of India 2013. Twelfth Five Year Plan (20122017), volume III, Social Sector, Planning Commission, New Delhi.

Government of India, National Sample Survey Office (NSSO) 2013. Key Indicators of Employment and Unemployment in India 2011-12, 68 ${ }^{\text {th }}$ Round, July 20011-June 2012, NSSO, Ministry of Statistics and Programme Implementation, New Delhi.

Government of India 2014. Fourth Annual Employment - Unemployment Survey (2013-14),Volume I, Labour Bureau, Ministry of Labour \& Employment, New Delhi.

Government of India 2015. Sample Registration System (SRS), Office of the Registrar General and Census Commissioner, Ministry of Home Affairs, New Delhi.

Government of India, Central Statistics Office (CSO), National Accounts Statistics (several years), Ministry of Statistics and Programme Implementation, New Delhi.

Government of India 2015. Seizing the Demographic Dividend- Chapter 2, Economic Survey of India 2014-15, Ministry of Finance, New Delhi.

Government of India 2015. Report of the Sub-group of Chief Ministers on Skill development, National Institution for Transforming India (NITI), New Delhi. 
Government of India 2015. National Policy for Skill Development and Entrepreneurship-2015, Ministry of Skill Development \& Entrepreneurship, New Delhi.

Government of India 2017. Annual Report 2016-17, Ministry of Skill Development \& Entrepreneurship, New Delhi.

Government of India, Ministry of Skill Development \& Entrepreneurship, National Skill Development Corporation and KPMG, Human Resource and Skill Requirements (2013-17, 2017-22), New Delhi.

NUEPA 2014. Unified District Information System for Education (U-DISE) 2013-14, New Delhi.

FICCI- Konrad Adenauer Stiftung 2015. Skill Development in India, New Delhi.

Mason, A., ed. 2001. 'Population Change and Economic Development in East Asia: Challenges Met, Opportunities Seized'. California.

Mehrotra, S., Gandhi, A., Saha, P. and Bimal, S.K. 2012. 'Joblessness and Informalisation: Challenges to Inclusive Growth in India', IAMR Occasional Paper No. 9/2012, Institute of Applied manpower Research, Planning Commission, Government of India, New Delhi.

Mehrotra, S., Gandhi, A. and Sahoo, B.K. 2013. 'Estimating India's Skill Gap on a Realistic Basis for 2022', Economic and Political Weekly, XIVIII(13): 102-11.
Sanghi, S. and Srija, A. 2015. 'Skill Development and Productivity of the Workforce', Economy Matters, Confederation of Indian Industry (CII), New Delhi, pp. 36-51.

Sasikumar, S.K. and Thimothy, R. 2013. 'Surmounting India's Employment Challenge: Evidence from NSSO Data (200405 to 2011-12)', Labour \& Development, 20(1): 1-18.

Sasikumar, S.K. and Thimothy, R. 2015. 'From India to the Gulf region: Exploring links between labour markets, skills and the migration cycle', ILO,GIZ, Federal Ministry of Economic Co-operation and Development, Germany Wheebox, India Skills Report, 2015, New Delhi.

Pant, A. 2017. 'Biggest challenge to India's growth: Low skill levels', Hindustan Times, retrieved from http:// www.hindustantimes.com/education/biggestchallenge-to-india-s-growth-low-skill-levels/storykHQYRMpvDE63uklLOuowaP.html

Pande, V. 2012. 'Himayat - A silent skills revolution in the making', Ideas for India, retrieved from http://www.ideasforindia. in/article.aspx?article=Himayat-A-silent-skills-revolutionin-the-making. 